Journal of Education and Teaching Learning (JETL)

Vol. 3, No. 1, 18-27 (2020)

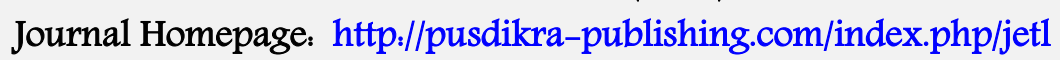

\title{
MENINGKATAN HASIL BELAJAR SISWA MELALUI PENERAPAN METODE DISKUSI PANEL PADA PEMBELAJARAN TEMA 1. DIRIKU DI KELAS II SD NEGERI 101881 PASAR VIII KECAMATAN TANJUNG MORAWA KABUPATEN DELI SERDANG
}

\begin{abstract}
Herlina*)
Abstrak

Jenis penelitian yang ditetapkan dalam penelitian ini adalah Penelitian Tindakan Kelas. Penelitian Tindakan Kelas (PTK) merupakan pencermatan dalam bentuk tindakan terhadap kegiatan belajar yang sengaja dimunculkan dan terjadi dalam sebuah kelas secara bersamaan. Bertujuan untuk memperbaiki proses pembelajaran dalam meningkatkan hasil belajar siswa melalui Metode Pembelajaran Diskusi Panel. Lokasi penelitian ini dilaksanakan di SD Negeri 101881 Pasar VIII Kecamatan Tanjung Morawa Kabupaten Deli Serdang.Subjek penelitian ini adalah siswa Kelas II SD Negeri 101881 Pasar VIII Kecamatan Tanjung Morawa Kabupaten Deli Serdang dengan jumlah siswa 21 orang. Yang terdiri dari 13 laki-laki dan 8 perempuan. Objek penelitian ini adalah peningkatan hasil belajar siswa pada Pembelajaran Tema 1. Hidup Rukun dengan menggunakan metode pembelajaran diskusi panel.Pada Siklus I,ternyata hanya 13 orang siswa $(61,90 \%)$ yang sudah memiliki ketuntasan belajar, sedangkan selebihnya yaitu 8 orang siswa $(38,09 \%)$ belum memiliki ketuntasan belajar. Nilai rata - rata yang diperoleh hanya mencapai 71,47 .Sedangkan pada siklus II dapat dilihat bahwa kemampuan siswa dalam melakukan tes hasil belajar secara klasikal sudah meningkat. Ternyata dari 21 orang siswa, terdapat 18 orang siswa yang tuntas $(85,71 \%)$ yang sudah memiliki ketuntasan belajar, sedangkan selebihnya yaitu 3 orang siswa $(14,28 \%)$ belum memiliki ketuntasan belajar. Nilai rata - rata yang diperoleh hanya mencapai 89,52.Berdasarkan hal ini, maka yang menjadi kesimpulan dalam penelitian ini adalah "Adanya Peningkatan Hasil Belajar Siswa Melalui Penerapan Metode Diskusi Panel Pada Pembelajaran Tema 1. Hidup Rukun Di Kelas II SD Negeri 101881 Pasar VIII Kecamatan Tanjung Morawa Kabupaten Deli Serdang".
\end{abstract}

Kata Kunci :Metode Diskusi Panel, Hasil Belajar, Tematik.

\section{PENDAHULUAN}

Dalam pembelajaran Tematik SD,diharapkan terjadi Reinvention (penemuan kembali).Penemuan kembali adalah menemukan suatu cara penyelesaian secara informal dalam pembelajaran di kelas. Pembelajaran Tematik harus terdapat keterkaitan antara pengalaman belajar siswa sebelumnya dengan konsep yang akan diajarkan. Sehingga diharapkan pembelajaran yang terjadi merupakan pembelajaran menjadi lebih bermakna

*) Penulis Adalah Guru SD NEGERI 101881 Pasar VIII Kec. Tanjung Morawa Kabupaten Deli Serdang 
(meaningful), siswa tidak hanya belajar untuk mengetahui sesuatu (learning to know about), tetapi juga belajar melakukan (learning to do), belajar menjiwai (learning to be), dan belajar bagaimana seharusnya belajar (learning to learn),serta bagaimana bersosialisasi dengan sesamateman (learning to live together).

Tematik merupakan alat untuk memberikan cara berpikir, menyusun pemikiran yang jelas, tepat, dan teliti. Tematik sebagai suatu obyek abstrak, tentu saja sangat sulit dapat dicerna anak-anak Sekolah Dasar (SD) yang mereka oleh Piaget, diklasifikasikan masih dalam tahap operasi konkret.Siswa SD belum mampu untuk berpikir formal maka dalam pembelajaran Tematik sangat diharapkan bagi para pendidik mengaitkan proses belajar mengajar di SD dengan benda konkret.

Pembelajaran Tematik di SD selalu mengacu kepada kurikulum SD yang telah ditetapkan oleh Dirjen Pendidikan yang disesuaikan dengan kebutuhan yang berkembang di masyarakat.Pengembangan kemampuan peserta didik dalam bidang Tematik merupakan salah satu kunci keberhasilan peningkatan kemampuan berpikir rasional dalam menyelesaikan permasalahan dalam kehidupan sehari-hari dengan kekritisan.

Dalam kegiatan pembelajaran, hasil belajar yang dicapai siswa kadang sesuai harapan, tetapi kadang-kadang tidak sesuai dengan yang diharapkan.Adapun faktor-faktor yang mempengaruhi proses dan hasil belajar setiap orang, diantaranya; faktor internal (dari dalam diri) dan faktor eksternal (luar diri) individu belajar.

Selain itu dalam pelaksanaan kegiatan pembelajaran Tematik, guru cenderung lebih mendominasi pembelajaran.Sehingga pembelajaran masih mengarah pada satu arah saja yang menyebabkan keaktifan siswa cenderung kurang. Salah satu dampak keaktifan siswa kurang akan menimbulkan pemahaman yang rendah terhadap materi Tema 1. Hidup Rukun. Terlebih lagi jika siswa hanya mendengarkan saja maka siswa akan mudah lupa dengan apa yang diajarkan. Maka dari itu perlu adanya cara untuk membuat siswa termotivasi untuk giat belajar dan bisa mendapatkan nilai yang diharapkan. Agar tujuan pembelajaran dapat tercapai maka pembelajaran Tematik haruslah berlangsung dengan melibatkan siswa, dalam artian pembelajaran berlangsung dengan efektif dan menyenangkan dengan berbagai metode pembelajaran.

Model pembelajaran adalah cara yang digunakan untuk mencapai pelajaran kepada siswa. Karena penyampaian itu berlangsung dalam interaksi edukatif, model 
pembelajaran dapat diartikan sebagai cara yang dipergunakan dalam mengadakan hubungan dengan siswa pada saat berlangsungnya pengajaran. Mengingat mengajar pada hakikatnya merupakan upaya dalam menciptakan situasi belajar, model yang digunakan oleh harus menumbuhkan berbagai kegiatan belajar bagi siswa sehubungan dengan mengajar.Untuk melaksanakan proses pembelajaran yang aktif, dan harus menentukan model pembelajaran yang tepat. Pertimbangan pokok dalam menentukan model pembelajaran terletak pada keefektifan proses pembelajaran.Setiap metode pembelajaran memiliki keunggulan dan kelemahan masing-masing.Tidak ada suatu model pembelajaran pun yang dianggap mampu untuk segala situasi.Hal ini bergantung pada pertimbangan situasi belajar mengajar yang relevan.

Metode diskusi panel adalah pembahasan suatu masalah yang dilakukan oleh beberapa orang panelis yang biasanya terdiri dari 4-5 orang dihadapan audiens.Diskusi panel berbeda dengan jenis diskusi lainnya.Dalam diskusi panel audiens tidak terlibat secara langsung, tetapi berperan hanya sekedar peninjau para panelis yang sedang melaksanakan diskusi.Oleh sebab itu, agar diskusi panel efektif perlu digabungkan dengan metode lain, misalnya dengan metode penugasan.Siswa disuruh untuk merumuskan hasil pembahasan dalam diskusi.

Dari latar belakang tersebut, perlu adanya perubahan melalui tindakan penelitian mengenai "Meningkatkan Hasil Belajar Siswa Melalui Penerapkan Metode Diskusi Panel Pada Pembelajaran Tema 1. Hidup Rukun Di Kelas II SD Negeri 101881 Pasar VIII Kecamatan Tanjung Morawa Kabupaten Deli Serdang".

\section{Hakikat Hasil Belajar.}

Berbagai macam pendapat serta pandangan dikemukakan oleh pakar pendidikan tentang pengertian "belajar" dan "hasil belajar" pada dasarnya terdapat kesamaan sebagai berikut: 1) belajar adalah terjadinya perubahan pada individu yang melakukan belajar, 2) hasil belajar adalah kemampuan individu setelah melalui proses belajar, meliputi belajar kognitif, efektif, dan psikomotor.

Seorang guru yang sedang mengajarkan suatu mata pelajaran, tidak hanya mengutamakan materi mata pelajaran saja, tetapi harus juga memperhatikan siswa itu sendiri sebagai manusia harus dikembangkan pribadinya (Nasution, 1992:119-122). 
Dengan pengetahuan dan keterampilan yang diperoleh siswa setelah melalui proses belajar diharapkan dapat digunakan atau diterapkan pada bidang-bidang lain, bukan hanya berguna dalam mata pelajaran tertentu yang telah diterimanya. Berbagai sumber dan media perlu dicari dan dikembangkan untuk memenuhi kebutuhan individu siswa. Oleh karena itu diperlukan pengetahuan dan kemampuan guru dalam menganalisis kemampuan awal dan karekteristik siswa.

Ada tiga hal yang diperlukan dalam menganalisis kerekteristik siswa : 1) karekteristik atau keadaan berkenaan dengan kemampuan awal dan psycho motor, 2) karakteristik berhubungan dengan latar belakang dan sosial kebudayaan 3) karakteristik berhubungan dengan perbedaan-perbedaan kepribadian (sikap, perasaan, minat dan lainlain).

Aunurrahman (2012:25) mendefenisikan, tentang hasil belajar adalah tingkat penguasaan yang dicapai oleh belajar dalam mengikuti program belajar mengajar sesuai dengan tujuan pendidikan yang telah ditetapkan.

Hasil belajar adalah kemampuan yang diperoleh siswa setelah melalui kegiatan belajar. Seperti yang diungkapkan Dimyati (2006:200) bahwa : "Hasil belajar merupakan penetuan nilai belajar siswa melalui kegiatan penilaian dan pengukuran dari proses belajar".

Dari beberapa pengertian diatas menurut penulis dapat disimpulkan bahwa hasil belajar adalah suatu kemampuan atau keterampilan yang dimiliki oleh siswa setelah siswa tersebut mengalami aktivitas belajar yang merupakan bentuk perubahan-perubahan kearah yang lebih baik yang diorientasikan pada prestasi belajar. Dimana prestasi belajar merupakan gambaran hasil belajar siswa dalam mengikuti proses belajar mengajar pada suatu jenjang yang diikutinya.

\section{Hakikat Model Diskusi Panel}

Rostiyah (2008:141) panel ialah pembicaraan yang sudah direncanakan di depan pengunjung tentang sebuah topik, hal mana diperlukan tiga panelis atau lebih dan seorang pemimpin atau moderator. Pada bagian lain Wina Sanjaya (2007: 157-158) mengatakan bahwa diskusi panel adalah pembahasan suatu masalah yang dilakukan oleh beberapa orang panelis yang biasanya terdiri dari 4-5 orang dihadapan audiens. Diskusi panel berbeda dengan jenis diskusi lainnya. Dalam Diskusi Panel audiens tidak terlibat secara 
langsung, tetapi berperan hanya sekedar peninjau para panelis yang sedang melaksanakan diskusi. Oleh sebab itu, agar diskusi panel efektif perlu digabungkan dengan metode lain, misalnya dengan metode penugasan. Siswa disuruh untuk merumuskan hasil pembahasan dalam diskusi.

Kemudian Rostiyah (2008: 141) menjelaskan tentang penggunaan panel dimana bila kita akan mengemukakan pendapat berbeda. Dapat dilaksanakan pula bila ada panelis yang memenuhi syarat atau kalau pokok pembicaraan terlalu luas untuk didiskusikan dalam kelompok itu. Perlu dipertimbangkan pula bila dipandang lebih baik untuk mengajak pengunjung agar "melihat ke dalamnya" tetapi tidak memberikan pendapat secara verbal ke dalam diskusi. Juga waktu mempertimbangkan keuntungan dan kerugian suatu pemecahan masalah. Terakhir bila panelis dan moderator bersedia untuk mempersiapkan diri.

\section{METODE PENELITIAN}

\section{A. Jenis Penelitian}

Jenis penelitian yang ditetapkan dalam penelitian ini adalah penelitian tindakan kelas.Penelitian Tindakan Kelas (PTK) merupakan pencermatan dalam bentuk tindakan terhadap kegiatan belajar yang sengaja dimunculkan dan terjadi dalam sebuah kelas secara bersamaan.Bertujuan untuk memperbaiki proses pembelajaran dalam meningkatkan hasil belajar siswa melalui Metode Pembelajaran Diskusi Panel.

\section{B. Lokasi Dan Waktu Penelitian}

Lokasi penelitian ini dilaksanakan di SD Negeri 101881 Pasar VIII Kecamatan Tanjung Morawa Kabupaten Deli Serdang.

\section{Subjek Dan Objek Penelitian}

Subjek penelitian ini adalah siswa Kelas II SD Negeri 101881 Pasar VIII Kecamatan Tanjung Morawa Kabupaten Deli Serdang dengan jumlah siswa 21 orang. Yang terdiri dari 13 laki-laki dan 8 perempuan. Objek penelitian ini adalah peningkatan hasil belajar siswa pada pembelajaran Tema 1. Hidup Rukun dengan menggunakan metode pembelajaran diskusi Panel.

\section{Metode Penelitian}


Metode penelitian ini adalah Penelitian Tindakan kelas ( Classroom Action Research). Pendekatan yang digunakan adalah pendekatan kualitatif yang berguna untuk mengungkapkan kesulitan belajar siswa dalam proses pembelajaran serta cara mengatasi kesulitan-kesulitan tersebut sebagai upaya untuk meningkatkan aktivitas belajar siswa pada materi tersebut.

Menurut Arikunto, (2010:16) menyatakan bahwa secara garis besar dalam tiap siklus itu terhadap empat tahap yang dilalui dalam melaksanakan penelitian tindakan kelas, yaitu perencanaan (planning), tindakan (acting), observasi (observing) dan refleksi (reflecting).

Pada setiap penelitian dalam ilmu pengetahuan umumnya bertujuan untuk menemukan dan mengembangkan serta menguji kebenaran dari suatu ilmu pengetahuan. Metode penelitian adalah cara yang dilakukan guru untuk mencapai maksud dan tujuan tertentu. Metode penelitian yang digunakan dalam penelitian ini adalah Penelitian Tindakan Kelas (Classroom Action Research).

Sesuai dengan langkah-langkah PTK maka pada tahap awal, Guru mempersiapkan materi yang akan disajikan, menyusun perencanaan perbaikan pembelajaran, serta menyiapkan alat dan media pembelajaran yang sesuai dan. Setelah melalui tahap persiapan, dan masuk ketahap tindakan yang merupakan perbaikan pembelajaran yang dibagi masing-masing dalam tiga siklus.Dan prosedur selanjutnya melakukan pengamatan, sedangkan perosedur terakhir dalam Penelitian Tindakan Kelas ini adalah melakukan refleksi.

\section{E. Desain Penelitian}

Penelitian ini dilakukan dalam dua siklus yang di dalamnya terdapat empat tahapan utama, yaitu perencanaan, tindakan, pengamatan dan refleksi seperti yang digambarkan dibawah ini:

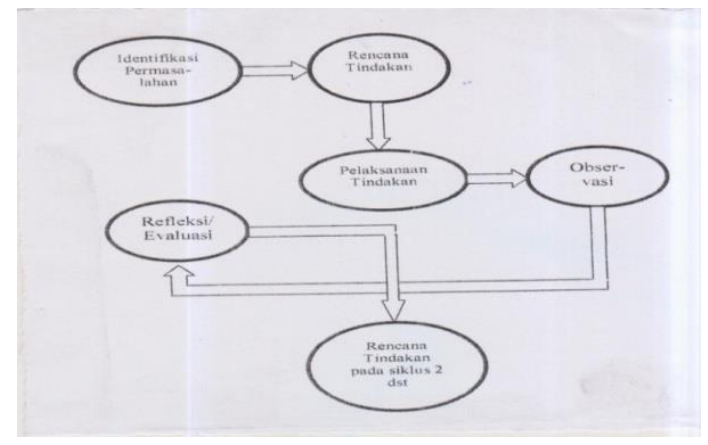


Gambar 3.1. Desain Penelitian Tindakan Kelas Menurut Ridwan Abdul Sani (2013:106).

\section{Siklus I dan II}

\section{a) Tahap Perencanaan}

Pada tahap perencanaan ini yang dilakukan adalah merencanakan tindakan yang akan dilakukan yaitu berupa skenario pembelajaran. Kegiatan yang dilakukan dalam tahap perencanaan siklus I dan II adalah sebagai berikut :

- Mengidentifikasi masalah dan menentukan alternatif pemecahannya.

- Membuat rencana pelaksanaan pembelajaran (RPP).

- Mempersiapkan pembelajaran dengan menggunakan metode diskusi Panel

- Mempersiapkan media, bahan, dan alat sumber belajar.

- Membuat lembar observasi untuk mengamati pembelajaran.

- Menyusun instrument penelitian untuk mengetahui tingkat keberhasilan siswa.

\section{b) Tahap Pelaksanaan Tindakan}

Setelah tahap perencanaan disusun, maka tahap selanjutnya adalah melaksanakan rencana pembelajaran yang telah direncanakan RPP. Pelaksanaan tindakan tersebut yaitu

- Membuka pembelajaran dengan memberikan motivasi kepada siswa.

- Menetapkan garis besar masalah yang akan dibahas yaitu materi Tema 1. Hidup Rukun.

- Membagi kelas menjadi 2 kelompok yaitu kelompok panelis dan kelompok pendengar

- Memilih ketua kelompok sebagai moderator, sekertaris sebagai notulen, dan penyaji

- Pada saat kelompok panelis mempresentasekan hasil diskusi, Tugas moderator memperdengarkan kepada para pendengar setiap peserta Panel

- Kelompok pendengar mengajukan pertanyaan kepada kelompok penyaji

- Selanjutnya bergantian kelompok yang mempresentasekan hasil diskusi mereka 
- Setelah kedua kelompok sudah tampil ke depan, masing-masing moderator menyimpulkan hasil diskusi mereka

- Menambahkan kesimpulan terhadap pembelajaran yang berlangsung dan memberikan arahan kepada siswa

- Memberikan tes hasil belajar kepada siswa

- Penutup

\section{c) Tahap Pengamatan}

Pengamatan dilakukan untuk mengetahui kesesuaian tindakan dengan rencana yang telah ditetapkan sekaligus mengetahui sejauh mana tindakan dapat menghasilkan perubahan yang sesuai dengan yang dikehendaki.Dan juga dapat melihat kesulitankesulitan yang dialami siswa sewaktu pembelajaran berlangsung.

\section{d) Tahap Refleksi}

Tahap refleksi dilakukan dengan mempertimbangkan pedoman mengajar yang dilakukan serta melihat kesesuaian yang dicapai dengan yang diinginkan dalam pembelajaran yang pada akhirnya di temukan kelebihan dan kekurangan, dimana jika ditemukan kekurangan maka akan dilakukan tindakan perbaikan pada siklus II.

Setelah siklus I dijalankan dan hasil yang dicapai belum sesuai dengan yang diharapkan, maka dilakukan kembali tahap-tahap diatas untuk dilakukan pada siklus II dan siklus selanjutnya sampai aktivitas belajar yang diharapkan tercapai. Pelaksanaan siklus II dilaksanakan setelah melakukan perbaikan-perbaikan pada rencana pembelajaran dan tindakan yang akan dilakukan dengan urutan-urutan seperti yang dilaksanakan pada siklus I.

\section{F. Instrumen Penelitian}

Untuk mengumpulkan data dalam penelitian ini, alat pengukur data yang digunakan adalah:

1) Tes

Tes adalah alat untuk mengetahui tentang pemahaman atau kemampuan siswa pada materi Tema 1. Hidup Rukun dengan pemberian soal.Tes yang diberikan adalah tes objektif dalam bentuk soal pilihan berganda 5 soal.

2) Lembar Observasi 
Lembar yang dilakukan merupakan pengamatan terhadap seluruh kegiatan pengajaran yang dilakukan.Kegiatan yang diamati meliputi aktivitas guru dan anak didik dalam pembelajaran.Observasi ini bertujuan untuk mengetahui kesesuaian tindakan dengan rencana yang telah disusun dan guna mengetahui sejauh mana pelaksanaan tindakan dapat menghasilkan perubahan yang sesuai dengan yang dikehendaki.

\section{HASIL PENELITIAN DAN PEMBAHASAN}

\section{A. Deskripsi Data Penelitian}

Lokasi penelitian ini dilaksanakan di SD Negeri 101881 Pasar VIII Kecamatan Tanjung Morawa Kabupaten Deli Serdang.Subjek penelitian ini adalah siswa kelas II SD Negeri 101881 Pasar VIII Kecamatan Tanjung Morawa Kabupaten Deli Serdang dengan jumlah siswa 21 orang.Objek penelitian ini adalah peningkatan hasil belajar siswa pada pembelajaran Tema 1. Hidup Rukun dengan menggunakan metode diskusi Panel.

Berikut ini data-data yang diperoleh dari hasil pengamatan dan pembelajaran dengan pendeskripsian data-data mengharapkan dapat menggambarkan data secara akurat.

Tabel 4.1. Deskripsi Data Penelitian Siswa Yang Tuntas

\begin{tabular}{|c|c|c|c|c|c|}
\hline No & Hasil Tes & $\begin{array}{c}\text { Jumlah Siswa } \\
\text { Yang Tuntas }\end{array}$ & Persentase & $\begin{array}{c}\text { Nilai } \\
\text { Rata-rata }\end{array}$ & $\begin{array}{c}\text { Keterangan } \\
\text { Klasikal }\end{array}$ \\
\hline 1 & Awal & 9 & $42,85 \%$ & 57,90 & Belum Tuntas \\
\hline 2 & Tes Siklus I & 13 & $61,90 \%$ & 71,47 & Belum Tuntas \\
\hline 3 & Tes Siklus II & 18 & $85,71 \%$ & 89,52 & Tuntas \\
\hline
\end{tabular}

Tabel 4.2. Deskripsi Data Penelitian Siswa Yang Tidak Tuntas

\begin{tabular}{|c|c|c|c|c|c|}
\hline No & Hasil Tes & $\begin{array}{c}\text { Jumlah Siswa } \\
\text { Yang Tidak } \\
\text { Tuntas }\end{array}$ & Persentase & $\begin{array}{c}\text { Nilai } \\
\text { Rata-rata }\end{array}$ & $\begin{array}{c}\text { Keterangan } \\
\text { Klasikal }\end{array}$ \\
\hline 1 & Awal & 12 & $57,14 \%$ & 57,90 & Belum Tuntas \\
\hline 2 & Tes Siklus I & 8 & $38,09 \%$ & 71,47 & Belum Tuntas \\
\hline 3 & Tes Siklus II & 3 & $14,28 \%$ & 89,52 & Tuntas \\
\hline
\end{tabular}

Adapun keberhasilan yang terjadi dalam pelaksanaan tindakan siklus II adalah sebagian besar siswa sudah mampu menguasai materi dengan baik dan benar. Hasil pengamatan refleksi II setelah dilaksanakan pengamatan dilaksanakannya tes kegiatan 
belajar mengajar pada siklus II diperoleh hasil bahwa "Terdapat Peningkatan Hasil Belajar Siswa Melalui Penerapan Metode Diskusi Panel Pada Pembelajaran Tema 1. Hidup Rukun di Kelas II SD Negeri 101881 Pasar VIII Kec. Tanjung Morawa Kabupaten Deli Serdang".

\section{KESIMPULAN}

Pada Siklus I,ternyata hanya 13 orang siswa $(61,90 \%)$ yang sudah memiliki ketuntasan belajar, sedangkan selebihnya yaitu 8 orang siswa $(38,09 \%)$ belum memiliki ketuntasan belajar. Nilai rata - rata yang diperoleh hanya mencapai 71,47 .Sedangkan pada siklus II dapat dilihat bahwa kemampuan siswa dalam melakukan tes hasil belajar secara klasikal sudah meningkat. Ternyata dari 21 orang siswa, terdapat 18 orang siswa yang tuntas $(85,71 \%)$ yang sudah memiliki ketuntasan belajar, sedangkan selebihnya yaitu 3 orang siswa $(14,28 \%)$ belum memiliki ketuntasan belajar. Nilai rata - rata yang diperoleh hanya mencapai 89,52.Berdasarkan hal ini, maka yang menjadi kesimpulan dalam penelitian ini adalah "Adanya Peningkatan Hasil Belajar Siswa Melalui Penerapan Metode Diskusi Panel Pada Pembelajaran Tema 1. Hidup Rukun Di Kelas II SD Negeri 101881 Pasar VIII Kecamatan Tanjung Morawa Kabupaten Deli Serdang".

\section{DAFTAR PUSTAKA}

Aunurrahman (2012). Belajar Dan Pembelajaran. Bandung: Alfabeta.

Dimiyati (2006). Proses Belajar Mengajar. Jakarta: Rineka Cipta.

Hamalik Oemar (2010). Belajar Dan Kesulitan-Kesulitan Belajar. Bandung: Tarsito.

Hamdani (2011). Strategi Belajar Mengajar. Bandung: Pustaka Setia.

Hamzah. B. Uno (2007). Model Pembelajaran (Menciptakan Proses Belajar Mengajar Yang Kreatif dan Efektif). Jakarta: Bumi Aksara.

Hamzah. B. Uno (2008). Belajar Dengan Pendekatan PAIKEM. Bandung : Bumi Aksara. Mulyasa, E. (2002). Standar Kompetensi Guru. Bandung : Remaja Rosdakarya. Noehi Nasution. (1992). Psikologi Pendidikan. Jakarta: Depdikbud.

Pupuh Faturrahman \& M.Sobry. (2007). Strategi Pembelajaran. Bandung: Insan Media Ridwan Abdul Sani (2013). Inovasi Pembelajaran. Jakarta : Bumi Aksara Rosmala Dewi (2010). Penelitian Tindakan Kelas. Medan : Pascasarjana Unimed. Rostiyah N.K. (2008). Strategi Belajar Mengajar. Jakarta: Rineka Cipta Slameto (2010). Belajar Dan Faktor-Faktor Yang Mempengaruhi. Jakarta : Rineka Cipta. Zaini, M. F. (2017). Hubungan Antara Kompetensi Profesionalisme Dengan Kinerja Guru Di MAN 3 Medan. Tadbir, 1, 19-26. 